\title{
Correction to: An analysis of the selection criteria for postgraduate physician assistant residency and fellowship programs in the United States
}

\author{
Vasco Deon Kidd ${ }^{1 *}$, Sarah Vanderlinden ${ }^{2}$ and Jennifer M. Spisak ${ }^{3}$
}

\section{Correction to: BMC Med Educ 21, 621 (2021)}

https://doi.org/10.1186/s12909-021-03059-y

Following publication of the original article [1], the author informed us that the response rate was incorrectly reported. The updated rate is given below and the changes have been highlighted in bold typeface as follows:

\section{Abstract}

Results: Twenty-three out of 73 postgraduate programs $\mathbf{( 3 1 . 5 \% )}$ responded to the survey. The study reported that applicant PAs and nurse practitioners (NPs) are largely selected on the basis of several factors.

\section{Results}

Seventy-three postgraduate programs were invited to participate, and 23 programs completed the entire survey. The overall response rate was $\mathbf{3 1 . 5 \%}$.

\section{Limitations}

Third, this study includes a low response rate of (31.5\%), which may have contributed to response bias.

The original article has been corrected.

\begin{abstract}
Author details
${ }^{1}$ School of Medicine, Department of Orthopaedic Surgery, University of California Irvine (UCI Health), 101 The City Dr S, Orange, CA 92868, USA. ${ }^{2}$ Department of Surgery, Trauma and Critical Care, Medical College of Wisconsin, Milwaukee, WI, USA. ${ }^{3}$ Ronald O. Perelman Department of Emergency Medicine, NYU Langone Health, 545 First Avenue, Greenberg Hall Suite 6B, New York, NY 10016, USA.
\end{abstract}

Published online: 18 February 2022

Reference

1. Kidd, et al. An analysis of the selection criteria for postgraduate physician assistant residency and fellowship programs in the United States. BMC Med Educ. 2021;21:621. https://doi.org/10.1186/s12909-021-03059-y. regulation or exceeds the permitted use, you will need to obtain permission directly from the copyright holder. To view a copy of this licence, visit http://creativecommons.org/licenses/by/4.0/. The Creative Commons Public Domain Dedication waiver (http://creativeco mmons.org/publicdomain/zero/1.0/) applies to the data made available in this article, unless otherwise stated in a credit line to the data. 